\title{
ARTÍCULOS
}

\section{Tree species richness, does it play a key role on a forest restoration plantation?}

\author{
Riqueza de especies arbóreas ¿juega un rol clave en la restauración forestal?
}

\author{
Ana Carolina Figueira Gazell a*, Ciro Abbud Righi a , José Luiz Stape ${ }^{\text {b }}$, Otávio Camargo Campoe c \\ *Corresponding author: a Universidade de São Paulo, Escola Superior de Agricultura “Luiz de Queiroz”, Departamento de Ciências \\ Florestais, Av. Pádua Dias, 11 - Caixa Postal 09 - CEP: 13418-900 - Piracicaba, SP, Brazil, ana.gazell@usp.br, ciro@usp.br \\ ${ }^{\mathrm{b}}$ Department of Forestry and Environmental Resources, North Carolina State University, USA. \\ ${ }^{c}$ Instituto de Pesquisa e Estudos Florestais (IPEF), Brazil.
}

\begin{abstract}
SUMMARY
The Brazilian Atlantic forest is considered one of the world's biodiversity conservation hotspot. Today there is less than ten percent remaining. Therefore it is necessary to restore these ecosystems. There are many ways of achieving restoration's main goals, but there is a lack of ecological studies that analyzes tree species richness as a variable. Thus, this study's goal is to investigate if there is a difference between a forest restoration in a gradient of tree species richness that varies from 20, 60 to 120 species, by using the litterfall as an indicator. Every month, for one year the forest litter was collected from litter traps that were previously installed. Results revealed that stands produced litterfall by the increasing gradient of species was of 5,370, 5,909 and 6,432 $\mathrm{kg} \mathrm{ha}^{-1} \mathrm{yr}^{-1}$. The statistical analyses revealed no significant difference among them. Therefore this six-year-old forest restoration plantation shows no difference on the litter production by the tree species richness.
\end{abstract}

Key words: Brazilian Atlantic rainforest, forest restoration, landscape ecology, tree biodiversity, forest litter production.

\section{RESUMEN}

El bosque atlántico brasileño es considerado un hotspot de la conservación mundial de la biodiversidad. Hoy hay menos de 10 \% de su área original. Por lo tanto, es necesario restaurar estos ecosistemas. Hay diversas maneras de alcanzar las principales metas de la restauración de los bosques, pero hay una falta de estudios ecológicos que analice la riqueza de especies de árboles como variable. Por lo tanto, el objetivo de este estudio fue investigar si hay una diferencia entre las restauraciones forestales en un gradiente de riqueza de especies de árboles que varía de 20, 60 a 120, usando la hojarasca como indicador. A cada mes, durante un año, esta fue recogida de las trampas de hojarasca previamente instaladas. Los resultados revelaron que la producción de hojarasca del bosque, en orden creciente de especies, fue de 5.370, 5.909 y $6.432 \mathrm{~kg} \mathrm{ha}^{-1} \mathrm{año}^{-1}$. Los análisis estadísticos no revelaron diferencia entre ellos. Consecuentemente, el bosque plantado de seis años de edad demostró que no hubo diferencia en la producción de hojarasca de la riqueza debido a la especies de árboles.

Palabras clave: selva atlántica brasileña, restauración forestal, ecología del paisaje, biodiversidad de árboles, producción de hojarasca.

\section{INTRODUCTION}

The Brazilian Atlantic rainforest is considered one of the world's conservation hotspot for its endemic species and biological diversity. Today there is only $8.10 \%$ of its original area, or, $99,944 \mathrm{~km}^{2}$, on patches that are disconnected and isolated from each other in the landscape, mostly by matrixes of agricultural plantations, such as, sugar cane and degraded grazing (Mittermeier et al. 1999).

Therefore it is necessary to restore the biome and to put into practice projects of ecological restoration of disturbed areas (Davis and Slobodkin 2004). The plantation of trees allows the reestablishment of ecological functional processes or environmental services (Hillebrand and Matthiessen 2009) such as of litter biomass production that protects soil from erosion, promotes biochemical and geochemical cycles (Golley et al. 1975, Pritchett 1979, Jordan 1985, Borders et al. 2006), also the forest stand planted by borders of rivers reconnects the isolated remaining fragmented forest by forming a corridor by the river (Hillebrand and Matthiessen 2009).

Forestry studies such as intensive management is discussed for reforestation projects of native ecosystems (Campoe et al. 2010), but there is a lack of ecological studies on restoration of rainforests considering different arrangements of species on tree stands. There is need to investigate if they play a role on achieving ecological restoration main goals more successfully (Davis and Slobodkin 2004, García and Martínez 2012). The species richness is the number of species in an area, and the evenness is 
how many individuals there is of each species (Hillebrand and Matthiessen 2009, García and Martínez 2012). Some studies reveals that the higher the diversity of species more biomass is produced by the forest stand and ecosystem (Golley et al. 1975, Wardle et al. 2006, Lorenzen et al. 2007).

The results of restoration efforts can be measured by the use ecological indicators, such as biomass production, basal area increment, or, volume per unit of area (Golley et al. 1975). Therefore, this work tries to answer if the tree species richness of plantations, under intensive forestry, plays an important role on reestablishing the environmental services of the forest, faster and closer to the aims of the ecological restoration, by using forest litter production as an indicator.

\section{METHODS}

This study was conducted in the Research Station of the Department of Forest Sciences (University of São Paulo) located at Anhembi, São Paulo, Brazil: $22^{\circ} 47^{\prime} \mathrm{S}$ and $48^{\circ} 09^{\prime} \mathrm{W}$. The climate data was collected during the research period. The average temperature was $21.9^{\circ} \mathrm{C}$, and the annual precipitation was $1,313.5 \mathrm{~mm}$. The trial area is located in the semideciduous atlantic forest (Cesar 1988). The plantation was done by September 2006, on a landscape of degraded grazing matrix of Brachiaria decumbens Stapf on a riparian area by the borders of Tiete River.

The experimental design has one factor of study is the tree species richness that had three levels of, 20, 60 and 120, native tree species. A total of 120 tree species are all native from the region were planted. Their proportion of ecological classes, suggested by (Budowski 1965, Denslow 1987) was even in all treatments on each plot, of $60 \%$ of pioneer and $40 \%$ of non-pioneer (secondary and climax).

The spacing used on the plantation was of $3.0 \mathrm{~m} \mathrm{x}$ $1.5 \mathrm{~m}$, and initial density was of 480 individuals per plot or 2,222 individuals ha-1. The plot size was $45 \mathrm{~m} \mathrm{x} 48 \mathrm{~m}$, 2,160 $\mathrm{m}^{2}$, or, 0.216 ha. Treatments were distributed totally randomly, and there were four plots per treatment. All trials had the same intensive forestry management. It consisted on the use of herbicide in doses of $7 \mathrm{~L} \mathrm{ha}^{-1}$ in implantation, and $5 \mathrm{~L} \mathrm{ha}^{-1}$ for the maintenance. Fertilization was done with $178 \mathrm{~kg} \mathrm{ha}^{-1}$ of triple superphosphate and 2,000 kg ha-1 of dolomite lime, $178 \mathrm{~kg} \mathrm{ha}^{-1}$ of fertilizer NPK 10:20:10 ratio in implantation and a dose for maintenance of $178 \mathrm{~kg}$ $\mathrm{ha}^{-1}$ of NPK 18:08:18. The control of ants was systematic and used baits.

The litter traps were installed on the useful plots, which consist of excluding the two borderlines on the perimeter of each plot. A total of three litter traps were installed randomly on each useful plot and placed at $0.5 \mathrm{~m}$ above the ground. The litter trap was a square of $0.5 \mathrm{~m}$ per $0.5 \mathrm{~m}$, or, $0.25 \mathrm{~m}^{2}$ areas. It was made of wooden frame with the bottom covered by a shading screen. Every month the litterfall was collected from the litter traps. All plant materials that would perhaps fall inside them were collected every month, from August 2011 until July 2012. It was then packed on brown paper bags, identified, and taken to the forced air oven, $65^{\circ} \mathrm{C}$. They were weighed on electronic scale of $0.01 \mathrm{~g}$ precision. The Tukey's test was done on SAS 9.2 software, considering $95 \%$ probability $(P<0.05)$.

\section{RESULTS}

All results of the litterfall were similar among treatments. The effect of seasonality was alike in all treatments, with higher deposition on dry months and lower on rainy months (figure 1, figure 2). It showed higher litterfall deposition on August 2011 and March 2012,

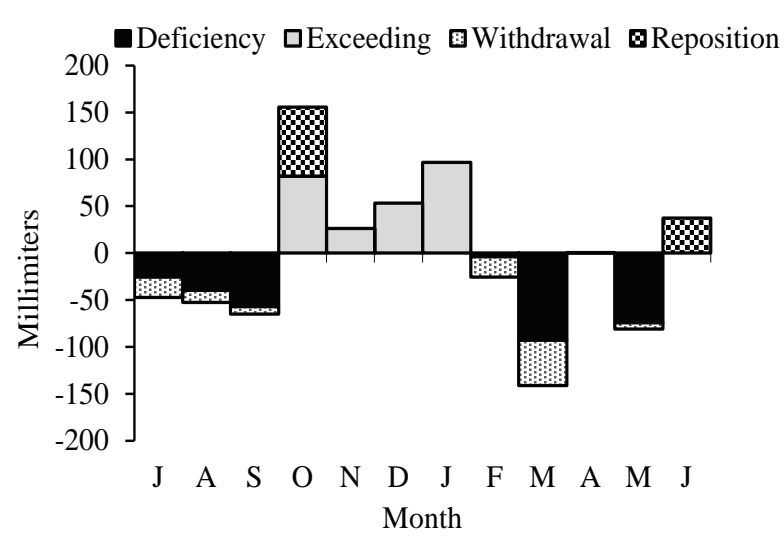

Figure 1. Pattern of the annual soil water balance ( $\mathrm{mm}$ ) for the period of the study. Calculations were done using a Thornthwaite-Mather Model (Thornthwaite 1948, Mather 1978).

Patrón del balance anual de agua del suelo $(\mathrm{mm})$ para el periodo de estudio. Los cálculos fueron hechos usando el Modelo Thornthwaite-Matter (1948-1978).

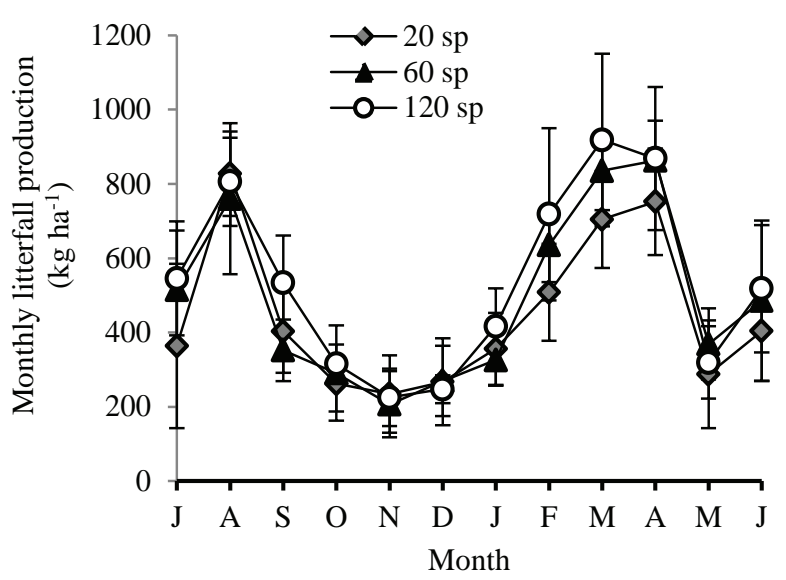

Figure 2. Monthly litterfall production. Bars represent the standard variation.

Producción mensual de hojarasca $\left(\mathrm{kg} \mathrm{ha}^{-1}\right)$. Las barras representan la desviación estándar. 
when precipitations were of $4 \mathrm{~mm}$ and $37.2 \mathrm{~mm}$, respectively. It diminished, until reaching its minimum on November 2011, month of the highest precipitation, $249.3 \mathrm{~mm}$.

The annual litterfall production was 5,370, 5,909 and $6,432 \mathrm{~kg} \mathrm{ha}^{-1} \mathrm{yr}^{-1}$ on treatments of 20,60, 120 species, respectively (figure 3 ). The 120 species treatment obtained, on average, $8.13 \%$ and $16.51 \%$ more litter biomass than the trials of 60 species and 20 species, correspondingly. Comparing the results with tropical forests of Panamá, the results were close. Golley (1975), obtained for the river Sabana site, 6,200 $\mathrm{kg} \mathrm{ha}^{-1} \mathrm{yr}^{-1}$ of litterfall.

The month mean litter production (figure 4) was 447.54, 492.43 and $536.03 \mathrm{~kg} \mathrm{ha}^{-1}$ month $^{-1}$. The results of the statistical analyses showed that there is no signi-

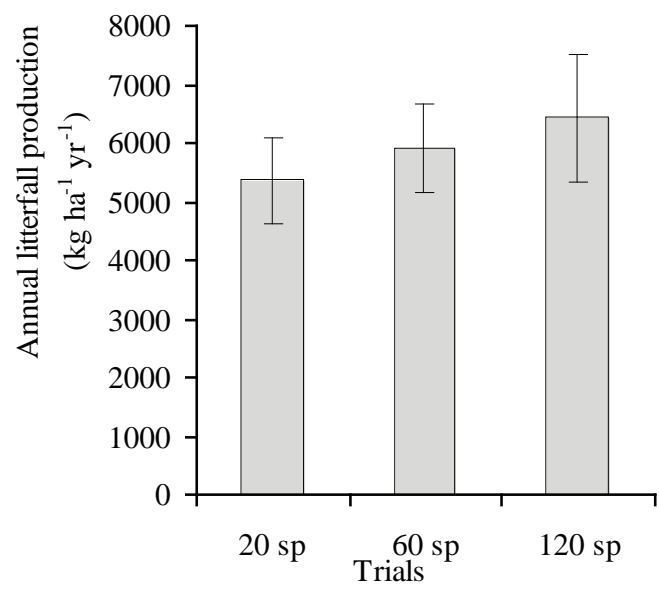

Figure 3. Annual litterfall production. Bars represent the standard variation.

Producción anual de hojarasca. Las barras representan la desviación estándar.

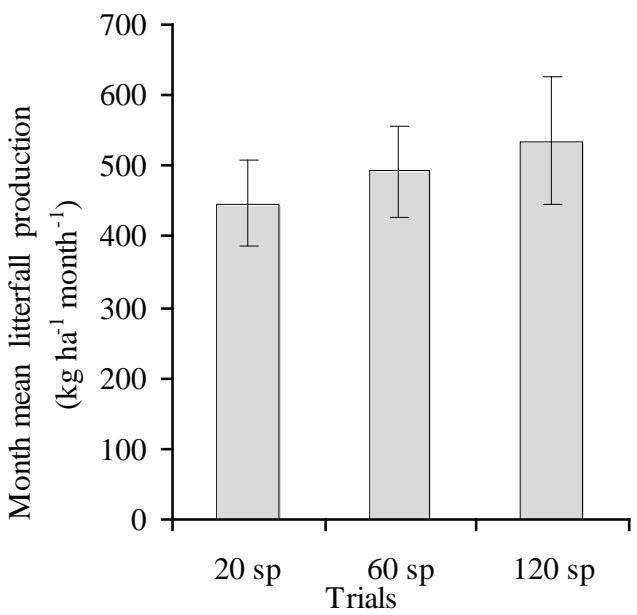

Figure 4. Month Mean litterfall production. Bars represent the standard variation.

Producción media mensual de hojarasca $\left(\mathrm{kg} \mathrm{ha}^{-1} \mathrm{mes}^{-1}\right)$. Las barras representan la desviación estándar. ficant difference on the litterfall production between the trials. The statistical analyses show that there are no significant differences between them for a $95 \%$ probability $(P<0.05)$.

\section{DISCUSSION}

Our results were similar to those found by Golley et al. (1975) in tropical forests in Panama obtained near the river Sabana site with 6,200 kg ha ${ }^{-1} \mathrm{yr}^{-1}$ of litterfall. A Costa Rican study conducted with four tree species (two native and two commercial tree species) produced 6,290 $\pm 480 \mathrm{~kg}$ ha $^{-1} \mathrm{yr}^{-1}$ and showed no statistical difference $(P<0.0001)$ in the young secondary forest site (7 - 9 year old) 5,430 \pm 390 $\mathrm{kg} \mathrm{ha}^{-1} \mathrm{yr}^{-1}$ (Celentano et al. 2011). The experiment of the United States Department of Agriculture (USDA) arboretum, established on 1960 in Puerto Rico shows that the litterfall of older forests are higher than younger forests plantations. In ten commercial tree species, the litterfall ranged from 14,300 down to $8,100 \mathrm{~kg} \mathrm{ha}^{-1} \mathrm{yr}^{-1}$, for Pinus caribea var hondurensis Barr y Golf. and Anthocephalus chinensis (Lam) A. Rich, respectively (Cuevas and Luego 1998).

\section{CONCLUSIONS}

The study reveals that this six-year rainforest restoration experiment does not have a relation between production of forest litter and tree species richness at this stage of the experiment. It may represent that further when the forest restoration gets older there are more chances to obtain a difference in annual litterfall among treatments. Probably, the tree species richness will play an effective role on litterfall production, when forest becomes more mature.

\section{ACKNOWLEDGMENTS}

Acknowledgments to, Grupo Florestal Monte Olimpo, professors Fernando Seixas, Fábio Poggiani, Paulo C. Sentelhas, forest engineer João Carlos T. Mendes, employees of EECFA and for the scholarship granted by Santander/USP.

\section{REFERENCES}

Borders BD, JC Pushnik, DM Wood. 2006. Comparison of leaf litter decomposition rates in restored and mature riparian forests on the Sacramento River, California. Restoration Ecology 14(12): 308-315.

Budowski G. 1965. Distribution of Tropical American Rainforest in the Light of Successional Process. Turrialba 15(1): 40-42.

Campoe OC, JL Stape, JCT Mendes. 2010. Can intensive management accelerate the restoration of Brazil's Atlantic forests? Forest Ecology and Management 259: 1808-1814.

Celentano D, RA Zahawi, B Finegan, RJ Cole, KD Holl. 2011. Litterfall dynamics under different Tropical Forest restoration strategies in Costa Rica. Biotropica 43(3): 279-287. 
Cesar O. 1988. Composição florística, fitossociologia e ciclagem de nutrientes em mata mesófila semidecídua (Fazenda Barreiro Rico, Município de Anhembi, SP). Master Thesis. Rio Claro, Brasil. Department of Ecology. São Paulo State University. 223 p.

Cuevas E, AE Luego. 1998. Dynamics of organic matter and nutrient return from litterfall in stands of ten tropical tree plantation species. Forest Ecology and Management 112:263279.

Davis MA, LB Slobodkin. 2004. The science and values of restoration ecology. Restoration Ecology 12: 1-3.

Denslow JS. 1987. Tropical rainforest gaps and trees species diversity. Evolution and Systematic 18: 31-451.

García D, D Martínez. 2012. Species richness matters for the quality of ecosystem services: a test using seed dispersal by frugivorous birds. Proceedings of Royal Society: Biological Sciences 279: 3106-3113.

Golley FB, JT McGinnis, RG Clements, GI Child, MJ Duever. 1975. Mineral cycling in a tropical moist forest ecosystem. Athens, USA. The University of Georgia Press. 256 p.

Hillebrand H, B Matthiessen. 2009. Biodiversity in a complex world: consolidation and progress in functional biodiversi- ty research. Ecology Letters 12: 1405-1419.

Jordan CF. 1985. Changes in nutrient cycles due to disturbance. In Jordan CF. Nutrient cycling in tropical forest ecosystems: principles and their application in management and conservation. Athens, USA. Institute of Ecology, University of Georgia Press. 89-146 p.

Lorenzen MS, JL Bonilla, C Potvin. 2007. Tree species richness affects litter production and decomposition rates in a tropical biodiversity experiment. Oikos 116: 2108-2124.

Mather JR. 1978. The climatic water balance in environmental analysis. Lexington, USA. Health and Company DC. 239 p.

Mittermeier RA, N Myers, PR Gil, CG Mittermeier (eds). 1999. Hotspots: earth's biologically richest and most endangered terrestrial ecoregions. Monterrey, México. CEMEX. 431 p.

Pritchett WL. 1979. Nutrient cycling in forest ecosystems. In Pritchett WL ed. Properties and management of forest soils. New York, USA. John Wiley. 180-204 p.

Thornthwaite CW. 1948. An approach toward a rational classification of climate. Geographical Review 38: 55-94.

Wardle DA, GW Yeates, GM Barker, KI Bonner. 2006. The influence of plant litter diversity on decomposer abundance and diversity. Soil Biology \& Biochemistry 38: 1052-1062.

Recibido: 24.05 .12

Aceptado: 10.10 .12 